\title{
SCREENING AND SOME PROPERTIES OF NEW MACROMOLECULAR PEPTIDE ANTIBIOTICS
}

\author{
Shigeyoshi Miyashiro* and Shigezo Udaka \\ Faculty of Agriculture, Nagoya University \\ Chikusa, Nagoya 464, Japan \\ (Received for publication July 12, 1982)
}

\begin{abstract}
In searching for macromolecular antitumor antibiotics of microbial origin, 2,875 kinds of Actinomycetes culture fluids were applied to a newly developed test system which consisted of antimicrobial assay using a macromolecule permeable mutant, DNA damage assay and mutagenicity test. As a result, 78 macromolecular antibiotics were found. Among them, 15 antibiotics precipitable with ammonium sulfate were macromolecular peptide antibiotics (protein antibiotics), of which molecular weight ranged from 10,000 to 14,000 .

Macromolecular peptide antibiotics AN-1, -5 and -15 , termed type I antibiotics, showed stronger growth inhibitory effect on the $u v r A$ and $r e c A$ mutants, as compared to the effect on their parent, MP2. They also had mutagenic activity. AN-7, -9, -16, -18, -20, -22, -23, -25 , and -26 , termed type U, exhibited an increased inhibitory activity to a rec $A$ mutant but did not to an uvr $A$ mutant. They all showed mutagenicity. AN-3, -11 and -13, type III antibiotics, gave similar influence on the DNA repair mutants, and on their parent, MP2. They had no mutagenic activity. Except for AN-11 and -13 of type III antibiotics, all antibiotics were inhibitory to the cell growth of a cancer cell, L1210.
\end{abstract}

Our previous paper ${ }^{1)}$ described a novel microbial system that was applicable to the screening of macromolecular antitumor antibiotics of microbial origin. The system consisted of 1) the system for isolation of macromolecular antibiotics based on macromolecule permeable property of a mutant, MP22,3), derived from Escherichia coli K-12,2) the system to detect inhibitor of DNA synthesis employing DNA repair mutants derived from MP2 and 3) the system to detect mutagenic activity of newly isolated antibiotics using a valine sensitive strain of MP2, whose conversion rate to valine resistance was dependent on mutagenic activity.

In this paper, the newly established test system was applied for screening of macromolecular peptide antibiotics producing Actinomycetes. As a result, 15 kinds of macromolecular peptide antibiotics were newly discovered. Among them, 13 samples showed inhibitory effect on the in vitro cell growth of a cancer cell, L1210.

\section{Materials and Methods}

Microorganisms

Escherichia coli K-12 W3876 and its macromolecule permeable mutant, MP2, were employed for the detection of macromolecular antibiotics. REC9, UV28, UR3 and L7 were derived from MP2 and described in the preceding paper ${ }^{1}$.

A number of Actinomycetes were newly isolated from various soil samples.

Cultivation of Actinomycetes

Actinomycetes were cultivated at $29^{\circ} \mathrm{C}$ in shake flasks. The culture media used were described in

* Present address: Central Research Laboratories, Ajinomoto Co., Kawasaki, Kanagawa, Japan. 
Table 1. Production media for macromolecular peptide antibiotics.

\begin{tabular}{|c|c|c|c|c|c|c|c|}
\hline (1) & GW & $\begin{array}{l}\text { Glucose } \\
\text { Polypepton } \\
\text { Meat extract } \\
\mathrm{NaCl} \\
\mathrm{CaCO}_{3} \\
\mathrm{pH}\end{array}$ & $\begin{array}{l}3.0 \% \\
0.5 \\
0.5 \\
0.5 \\
0.3 \\
7.0\end{array}$ & \multirow{2}{*}{\multicolumn{2}{|c|}{ (4) GSS }} & \multirow{2}{*}{$\begin{array}{l}\text { Starch } \\
\text { Glucose } \\
\text { Polypepton } \\
\text { Meat extract } \\
\mathrm{K}_{2} \mathrm{HPO}_{4} \\
\mathrm{NaCl} \\
\mathrm{CuSO}_{4} \cdot 5 \mathrm{H}_{2} \mathrm{O} \\
\mathrm{FeSO}_{4} \cdot 7 \mathrm{H}_{2} \mathrm{O} \\
\mathrm{MnCl}_{2} \cdot 4 \mathrm{H}_{2} \mathrm{O} \\
\text { pH }\end{array}$} & \multirow{2}{*}{$\begin{array}{l}2.5 \% \\
1.0 \\
0.5 \\
0.5 \\
0.1 \\
0.3 \\
100 \mu \mathrm{g} / \mathrm{ml} \\
1 \mu \mathrm{g} / \mathrm{ml} \\
1 \mu \mathrm{g} / \mathrm{ml} \\
7.0\end{array}$} \\
\hline (2) & GWD & \multicolumn{2}{|c|}{$\begin{array}{l}0.5 \% \text { dried yeast was added to } \\
\text { the GW }\end{array}$} & & & & \\
\hline (3) & GM & \multicolumn{2}{|c|}{$\begin{array}{l}20 \mu \mathrm{g} / \mathrm{ml} \mathrm{MnCl} \mathrm{MnC}_{2} \cdot 4 \mathrm{H}_{2} \mathrm{O} \text { was added } \\
\text { to the } \mathrm{GWD} \text { and } \mathrm{CaCO}_{3} \text { was } \\
\text { replaced by } 0.2 \% \mathrm{CaCl}_{2} \cdot 2 \mathrm{H}_{2} \mathrm{O}\end{array}$} & (5) & GSCZ & \multicolumn{2}{|c|}{$\begin{array}{l}500 \mu \mathrm{g} / \mathrm{ml} \mathrm{ZnSO}_{4} \cdot 5 \mathrm{H}_{2} \mathrm{O} \text { was } \\
\text { added to the GSS }\end{array}$} \\
\hline
\end{tabular}

Table 1. The supernatant of each culture broth after centrifugation was subjected to the screening test.

Determination of Antibacterial Activity

Quantitative determination of antibacterial activity was done by the disk assay using UR $3^{1}$. The diameter of inhibition zone was proportional to the logarithm of antibacterial activity. One unit of antibacterial activity was defined as the antibiotic concentration to give $10 \mathrm{~mm}$ (diameter) of inhibition zone.

\section{Cell Culture of L1210}

In order to examine antitumor activity of newly isolated antibiotics, their inhibitory effect on the growth of cancer cells was examined. A cancer cell, L1210 was cultured in Eagle minimum essential medium supplemented with $10 \%$ calf serum, $5 \mu \mathrm{g} / \mathrm{ml}$ of cefazolin and $100 \mu \mathrm{g} / \mathrm{ml}$ of streptomycin at $37^{\circ} \mathrm{C}$ in a $7 \% \mathrm{CO}_{2}$ incubater.

\section{Analysis}

Molecular weight of macromolecular peptide antibiotics was determined by chromatography on a column $(1.5 \times 30 \mathrm{~cm})$ of Bio-Gel P30 using $0.02 \mathrm{M}$ phosphate buffer containing $0.1 \mathrm{M} \mathrm{NaCl}(\mathrm{pH} 7.0)$ as an eluting buffer (flow rate was $0.05 \mathrm{ml} /$ minute). Blue dextran 2,000, myoglobin (MW 17,600), cytochrome C (MW 12,500) and bacitracin (MW 1,400) were used as standard.

BIURET, ninhydrin and anthrone reactions were done by the method of WESTLEY and LAMBETH ${ }^{4}$, BLACKBURN $^{5)}$ and SPIRO $^{(8)}$, respectively.

\section{Results}

\section{Screening of Macromolecular Antibiotics}

Culture fluids of various Actinomycetes were subjected to the macromolecular antibiotic detecting system in which macromolecule permeable mutant MP2 was employed. As reported in the preceding paper, among 2,875 samples tested 78 samples showed strong growth inhibitory effect on MP2 ${ }^{1}$. Therefore, the molecular weight of these antibiotics seemed to be more than 1,200. Furthermore, active fractions of 15 out of 78 samples were precipitated from culture fluids by saturating with ammonium sulfate. These 15 samples were chosen as macromolecular peptide antibiotics to be investigated further in detail.

\section{DNA Damage Assay and Mutagenicity Test for 15 Antibiotics}

The 15 newly isolated antibiotics were subjected to both DNA damage assay and mutagenicity test, and classified into three groups as shown in Table 2. An uvrA mutant, UV28 was more sensitive to DNA binding antibiotics such as actinomycin $\mathrm{D}$, mitomycin $\mathrm{C}$ and adriamycin as compared to its parental strain MP2 ${ }^{1)}$. On the other hand, a recA mutant of MP2, REC9 became more sensitive not only to the DNA binding antibiotics but also to the DNA degrading antibiotics such as neocarzinostatin 
Table 2. Effect on DNA repair and mutagenesis of various macromolecular peptide antibiotics.

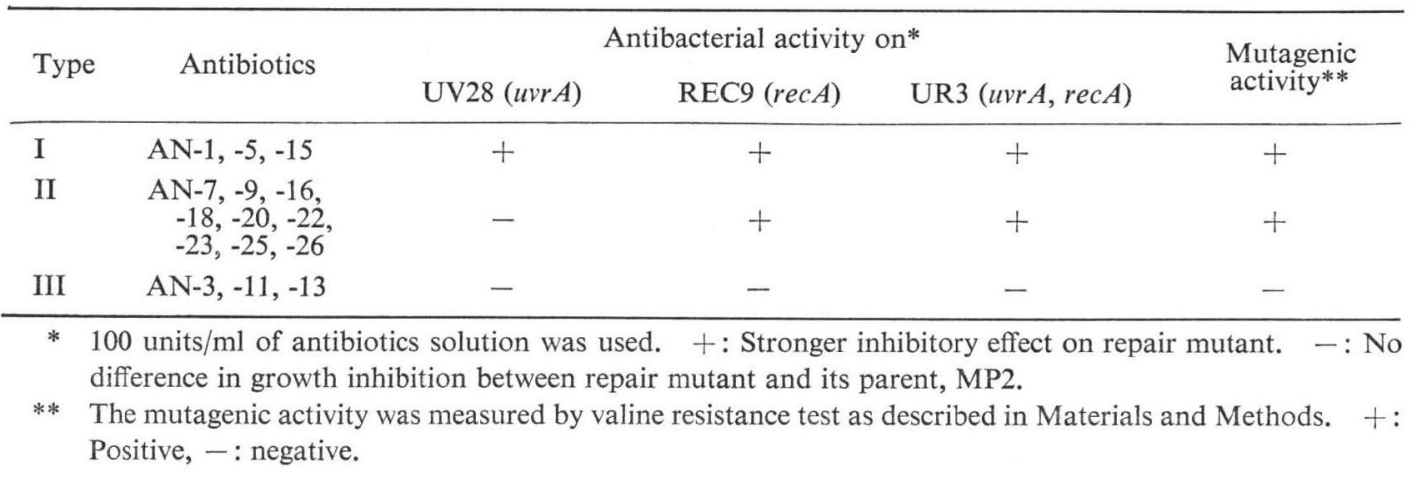

and bleomycin ${ }^{1)}$. Type I antibiotics, which included AN-1, -5 and -15 , showed slightly increased toxicity to both UV28 and REC9 and also had mutagenic activity. Type II, which included AN-7, -9, -16, $-18,-20,-22,-23,-25$ and -26 , showed increased toxicity to REC9, but did not show it to UV28. Type II also showed mutagenicity. Therefore, properties of type II antibiotics were similar to that of neocarzinostatin. Type III, which included AN-3, -11 and -13 , did not exhibit increased toxicity both to UV28 and REC9. Mutagenic activity was not detected in type III antibiotics.

\section{Purification and Some Properties of 15 Antibiotics}

The 15 different macromolecular peptide antibiotics were purified according to the procedure shown in Fig. 1. The active fraction was precipitated by adding ammonium sulfate. The precipitate was dissolved in $0.02 \mathrm{M}$ phosphate buffer ( $\mathrm{pH} 7.2$ ) containing $0.1 \mathrm{M} \mathrm{NaCl}$ and then dialyzed for 24 hours at $5^{\circ} \mathrm{C}$ against the same buffer. The nondialyzable protein was applied to Sephadex G-25 gel filtration. More than $20 \%$ of the activity was recovered from the culture broth with this purification procedure. Specific activity of each sample ranged between 17 and 820 units/mg protein as shown in Table 3. Some physicochemical properties were presented in Table 4. Molecular weight of 15 antibiotics ranged from 10,000 to 14,000 and UV maxima of the samples existed between 252 and $278 \mathrm{~nm}$. These properties indicated polypeptide nature of the antibiotics. AN-18 and AN-20 gave positive Anthrone reaction and their UV maxima was $252 \mathrm{~nm}$. Therefore, the two antibiotics may contain nucleoside structure in their molecules.

Fig. 1. Isolation procedure of macromolecular peptide antibiotics.

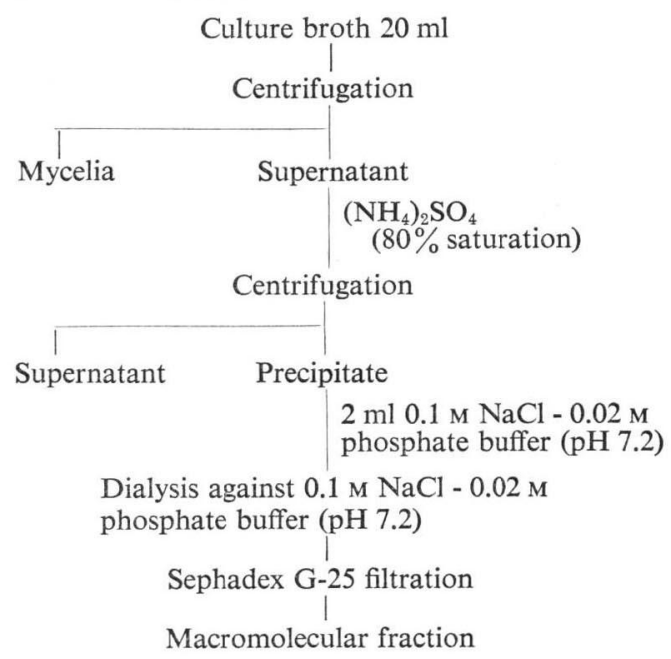

Effect of Newly Isolated Macromolecular Peptide Antibiotics on the Growth of L1210 Cells

Antitumor activity of the 15 newly isolated macromolecular antibiotics was examined by utilizing in vitro culture of L1210 cells. As shown in Table 5, all of the antibiotics belonging to the type I and II exhibited antitumor activity. Among them, AN-1, -5 of type I and AN-7, -16, -22, -23 and -25 of 
Table 3. Production of macromolecular peptide antibiotics and their antibacterial activities.

\begin{tabular}{|c|c|c|c|c|}
\hline Antibiotics & Producing strains & $\begin{array}{l}\text { Production } \\
\text { media }\end{array}$ & $\begin{array}{l}\text { Antibiotics } \\
\text { produced } \\
\text { (unit/ml) }\end{array}$ & $\begin{array}{l}\text { Specific antibacterial } \\
\text { activity of partially } \\
\text { purified fraction } \\
\text { (unit/mg protein) }\end{array}$ \\
\hline AN- 1 & S. albus AJ9003 & GWD & 50 & 326 \\
\hline AN- 3 & AAP-23 & GSS & 42 & 80 \\
\hline AN- 5 & G-36 & GW & 50 & 120 \\
\hline AN- 7 & B-19 & GM & 50 & 820 \\
\hline AN- 9 & B-20 & GSS & 120 & 820 \\
\hline AN-11 & $\mathrm{AAC}-4$ & GSS & 42 & 80 \\
\hline $\mathrm{AN}-13$ & AAP-21 & GSS & 42 & 80 \\
\hline AN-15 & S. albus AJ9081 & GSS & 17 & 80 \\
\hline AN-16 & $\mathrm{J}-24$ & GM & 8 & 720 \\
\hline AN-18 & No. 454 & GSCZ & 84 & 17 \\
\hline AN-20 & No. 463 & GSCZ & 84 & 17 \\
\hline AN-22 & I-101 & GM & 50 & 650 \\
\hline AN-23 & $\mathrm{I}-502$ & GM & 50 & 650 \\
\hline AN-25 & $\mathrm{K}-506$ & GM & 50 & 720 \\
\hline AN-26 & No. 163 & GWM & 140 & 34 \\
\hline
\end{tabular}

Table 4. Some characteristics of macromolecular peptide antibiotics.

\begin{tabular}{|c|c|c|c|c|c|}
\hline \multirow{2}{*}{ Antibiotics } & \multirow{2}{*}{$\begin{array}{l}\text { Molecular weight } \\
\times 10^{4}\end{array}$} & \multicolumn{3}{|c|}{ Color reaction* } & \multirow{2}{*}{$\mathrm{UV}_{\max }$} \\
\hline & & BIURET & Ninhydrin & Anthrone & \\
\hline AN- 1 & $1.1 \sim 1.3$ & ++ & + & \pm & $270 \mathrm{~nm}$ \\
\hline AN- 3 & $1.3 \sim 1.4$ & ++ & + & - & 278 \\
\hline AN- 5 & $1.2 \sim 1.3$ & ++ & + & - & 270 \\
\hline AN- 7 & $1.0 \sim 1.3$ & ++ & + & \pm & 270 \\
\hline AN- 9 & $1.2 \sim 1.3$ & ++ & + & \pm & 270 \\
\hline AN-11 & $1.3 \sim 1.4$ & ++ & + & - & 278 \\
\hline AN-13 & $1.3 \sim 1.4$ & ++ & + & - & 278 \\
\hline AN-15 & $1.3 \sim 1.4$ & ++ & + & - & 278 \\
\hline AN-16 & $1.0 \sim 1.3$ & ++ & + & - & 270 \\
\hline AN-18 & $1.0 \sim 1.3$ & ++ & + & + & 252 \\
\hline AN-20 & $1.0 \sim 1.3$ & ++ & + & + & 252 \\
\hline AN-22 & $1.0 \sim 1.3$ & ++ & + & - & 270 \\
\hline AN-23 & $1.0 \sim 1.3$ & ++ & + & - & 270 \\
\hline AN-25 & $1.0 \sim 1.3$ & ++ & + & - & 270 \\
\hline AN-26 & $1.3 \sim 1.4$ & ++ & + & - & 276 \\
\hline
\end{tabular}

* $1.5 \mathrm{mg} / \mathrm{ml}$ of solution was used.

type II showed prominent activity in that the antibiotic concentration giving $50 \%$ growth inhibition was as low as 0.25 unit/ml. Two samples, AN-11 and -13 out of three antibiotics of type III had no effect on growth of L1210. However, AN-3 of type III showed marked inhibitory effect on the growth of L1210 cells. 
Table 5. Effect of macromolecular peptide antibiotics on growth of mouse leukemia L1210 cells.

\begin{tabular}{|c|c|c|c|c|c|c|c|c|c|}
\hline \multirow{3}{*}{ Type* } & \multirow{3}{*}{ Antibiotic } & \multicolumn{8}{|c|}{ Growth inhibition of L1210** } \\
\hline & & \multicolumn{7}{|c|}{ Dose (unit/ml) } & \multirow[b]{2}{*}{0.05} \\
\hline & & 10 & 5 & 2.5 & 1 & 0.5 & 0.25 & 0.1 & \\
\hline \multirow{3}{*}{ I } & $\mathrm{AN}-1$ & +++ & +++ & +++ & ++ & ++ & + & + & - \\
\hline & AN-5 & +++ & ++ & ++ & + & - & - & - & - \\
\hline & $\mathrm{AN}-15$ & + & - & - & - & - & - & - & - \\
\hline \multirow{9}{*}{ II } & AN-7 & +++ & +++ & +++ & +++ & +++ & ++ & + & - \\
\hline & AN-9 & + & - & - & - & - & - & - & - \\
\hline & AN-16 & +++ & +++ & +++ & +++ & +++ & ++ & + & - \\
\hline & AN-18 & ++ & + & - & - & - & - & - & - \\
\hline & AN-20 & ++ & + & - & - & - & - & - & - \\
\hline & AN-22 & +++ & +++ & +++ & +++ & +++ & ++ & + & - \\
\hline & AN-23 & +++ & +++ & +++ & +++ & +++ & ++ & + & - \\
\hline & AN-25 & +++ & +++ & +++ & +++ & +++ & ++ & + & - \\
\hline & AN-26 & +++ & + & - & - & - & - & - & - \\
\hline \multirow{3}{*}{ III } & AN-3 & +++ & +++ & +++ & ++ & ++ & - & - & - \\
\hline & AN-11 & - & - & - & - & - & - & - & - \\
\hline & AN-13 & - & - & - & - & - & - & - & - \\
\hline
\end{tabular}

* See Table 2.

** -, No growth inhibition; + , about $25 \%$ inhibition; ++ , about $50 \%$ inhibition;,$+++ 100 \%$ inhibition.

\section{Discussion}

Macromolecular peptide antibiotics such as neocarzinostatin ${ }^{7 \sim 10)}$ and macromomycin ${ }^{11 \sim 14)}$ appeared particularly important and useful as antitumor agents as they are expected to have a high specificity and strong activity against tumor cells as compared to small molecular antibiotics. From this viewpoint, we developed a microbial screening system for a macromolecular antitumor antibiotics as described in our previous paper ${ }^{1)}$. We applied this new assay system to many kinds of Actinomycetes culture fluids, and succeeded to obtain 15 macromolecular antibiotics. These antibiotics appeared to be mostly polypeptides of about 10,000 daltons (Table 4). Since they were not extensively purified, some nonproteinaceous characteristics such as absorption maximum other than $280 \mathrm{~nm}$ might be merely due to contaminants. Thus, an approximate frequency to find macromolecular peptide antibiotics was one in every 200 strains of Actinomycetes.

There are more than a dozen of proteinaceous antibiotics so far reported, but only a few have been studied carefully ${ }^{15 \sim 26)}$. On first inspection, most of the known macromolecular antibiotics appeared to be different from ours in regard to their chemical and biological properties.

Table 6. Grouping of newly isolated macromolecular peptide antibiotics.

\begin{tabular}{|c|c|c|c|}
\hline Interaction with DNA & $\begin{array}{l}\text { Mutagenic } \\
\text { activity }\end{array}$ & $\begin{array}{l}\text { Macromolecular peptide } \\
\text { antibiotics obtained } \\
\text { by our screening }\end{array}$ & $\begin{array}{l}\text { Known antitumor } \\
\text { antibiotics }\end{array}$ \\
\hline \multicolumn{4}{|c|}{ Detected with DNA damage assay } \\
\hline \multirow{2}{*}{ DNA-binding type } & $\int$ Positive & $\mathrm{AN}-1,-5,-15$ & Mitomycin C \\
\hline & Not detected & Not found & Actinomycin D \\
\hline \multirow{2}{*}{ DNA-degrading type } & $\int$ Positive & $\mathrm{AN}-7,-9,-16,-18,-20$, & Neocarzinostatin \\
\hline & Not detected & Not found & Bleomycin \\
\hline \multicolumn{4}{|c|}{ Not detected with DNA damage assay } \\
\hline & Not detected & AN-3, $-11,-13$ & \\
\hline
\end{tabular}


The antibiotics obtained were classified into three groups in relation to their properties of interaction with DNA and mutagenic activities (Table 6). Type I antibiotics had DNA-binding activity and showed mutagenicity. Adriamycin and mitomycin $\mathrm{C}$ seemed to belong to this group but such proteinlike antibiotics has not probably been reported previously. Type II had characteristics of DNA-degrading type rather than DNA binding. They also showed mutagenicity. Biological activities of this group's antibiotics resembled those of neocarzinostatin. Type III showed neither DNA-binding nor DNA-degrading activity and had no mutagenic activity.

Newly isolated antibiotics of type I and II are expected to have antitumor activity since they inhibited in vitro cell growth of L1210. Their antitumor activities are now being tested in an in vivo assay. Among type III antibiotics, only AN-3 had inhibitory effect on L1210 cell growth. AN-3 showed neither DNA-binding nor degrading activity. But our further study on AN-3 indicated that it inhibited the incorporation of $\left[{ }^{3} \mathrm{H}\right]$ thymidine into DNA. Therefore, AN-3 was considered to interact with DNA inhibiting its synthesis in an unknown manner.

\section{References}

1) Udaka, S. \& S. Miyashiro: A new test system for screening macromolecular antitumor antibiotics and its application to culture fluids of Actinomycetes. J. Antibiotics 35: 1312 1318, 1982

2) OHISH, T. \& S. Udaka: Mutant of Escherichia coli sensitive to proteinase. Curr. Microb. 1: 273 276, 1978

3) OHISHI, T.; H. Yamagata \& S. UdAKA: Mutant of Escherichia coli hypersensitive to an antitumor protein: neocarzinostatin. Agric. Biol. Chem. 43: 371 378, 1979

4) Westley, J. \& J. Lambeth: Protein determination on the basis of copper-binding capacity. Biochim. Biophys. Acta 40: 364 366, 1960

5) Blackburn, S.: “Amino Acid Determination”, pp. 69 79, Marcel Dekker, Inc., New York, 1968

6) SpIro, R. G.: "Methods in Enzymology" Vol. 8. pp. 3 26, Academic Press, New York, 1966

7) Ishida, N.; K. Miyazaki, K. Kumagai \& M. Rikimaru: Neocarzinostatin, an antitumor antibiotic of hight molecular weight: Isolation, physicochemical properties and biological activities. J. Antibiotics, Ser. A 18: 68 76, 1965

8) Meithofer, J.; H. Maeda, C. B. Glaser, J. Czombos \& K. Kumomizu: Primary structure of neocarzinostatin an antitumor protein. Sience 178: 875 876, 1972

9) Bradner, W. T. \& D. J. Hutchison: Neocarzinostatin (NSC-69856): an antitumor antibiotic effective against ascite leukemia L1210 in mice. Cancer Chemoth. Rept. 5: 79 84, 1966

10) D'Andrea, A. D. \& W. A. Haseltine: Sequence specific cleavage of DNA by the antitumor antibiotics neocarzinostatin and bleomycin. Proc. Natl. Acad. sci. USA 75: 3608 3612, 1978

11) Chimura, H.; M. Ishizuka, M. Hamada, S. Hori, K. Kimura, J. Iwanaga, T. Takeuchi \& H. Umezawa: A new antibiotic, macromomycin, exhibiting antitumor activity and antimicrobial activity. J. Antibiotics 21: 44 49, 1968

12) Yamashita, T.; N. Naol, K. Watanabe, T. Takeuchi \& H. Umezawa: Further purification and characterization of macromomycin. J. Antibiotics 29: 415 423, 1976

13) Hidaka, T.; Y. Yano, T. Yamashita \& K. Watanabe: Biological activity of macromomycin. J. Antibiotics 32: 340 3461979

14) Suzuki, H.; T. Nishimura, K. Muto \& N. Tanaka: Mechanism of action of macromomycin: DNA strand scission, inhibition of DNA synthesis and mitosis. J. Antibiotics 31: 875 883, 1978

15) Hosoya, S.: Carcinomycin (Gannmycin), new antitumor antibiotic. Chemotherapy 3: 128 131, 1955

16) Harada, Y.; T. Nara \& F. OKamoto: Studies on carzinocidin, an antitumor substance, produced by Streptomyces sp. I. On extraction, chemical and biological properties of carzinocidin. J. Antibiotics, Ser. A 9: 6 8, 1956

17) Sugawara, R.; A. Matsumae \& T. Hata: Melanomycin, a new antitumor substance from Streptomyces. I. J. Antibiotics, Ser. A 10: 133 137, 1957

18) SoEdA, M. \& M. Mitomi: Chemical studies on marinamycin. II. Fundamental chemical studies on marinamycin. J. Antibiotics, Ser. A 15: 182 186, 1962

19) Sнōı, J.: Preliminary studies on the isolation of carzinostatin complex and its characteristics. (Studies on the Streptomyces antibiotics. XXXXIII) J. Antibiotics, Ser. A 14: 27 33, 1961

20) Murase, M.; T. HikiJi, K. Nitta, Y. Okami, T. Takeuchi \& H. Umezawa: Peptimycin, a product of 
Streptomyces exhibiting apparent inhibition against Ehrlich carcinoma. J. Antibiotics, Ser. A 14: 113 118, 1961

21) Schmitz, H.; W. T. Bradner, A. Gourevitch, B. Heinemann, K. E. Price, J. Lein \& I. R. Hooper: Actinogan, a new antitumor agent obtained from Streptomyces. I. Chemical and biological properties. Cancer Res. 22: 163 166, 1962

22) Suhara, Y.; M. Ishizuka, H. Naganawa, M. Hori, M. Suzuki, Y. OKami, T. Takeuchi \& H. Umezawa: Studies on enomycin, a new antitumor substance. J. Antibiotics, Ser. A 16: 107 108, 1963

23) InOuYe, S.: The isolation and characterization of the two macromolecular antitumor agents from Streptomyces. Agric. Biol. Chem. 26: 563 571, 1962

24) Nomura, S.; H. Yamamoto, A. Matsumae \& T. Hata: Iyomycin, a new antitumor antibiotic from Streptomyces. I. Isolation and properties of iyomycin complex. J. Antibiotics, Ser. A 17: 104 111, 1964

25) Ogawara, H.; K. Maeda, K. Nitta, Y. Okami, T. Takeuchi \& H. Umezawa: An antibiotic, plurallin, consisting of a pluramycin-like prosthetic group and a glycoprotein. J. Antibiotics, Ser. A 19: 1 9, 1966

26) Oki, T.; A. Yoshimoto, Y. Matsuzawa, S. Hori, H. Tone, A. Takamatsu, T. Takeuchi, M. Ishizuka, M. HAMADA \& H. UMEZAWA: A macromolecular antitumor antibiotic: Macracidomycin. J. Antibiotics 28: $479 \sim 482,1975$ 